\title{
Short communication: Growth hormone receptor expression in two dairy breeds during the periparturient period
}

\author{
C. S. Okamura, J. F. Bader, D. H. Keisler, and M. C. Lucy ${ }^{1}$ \\ Division of Animal Sciences, University of Missouri, Columbia 65211
}

\section{ABSTRACT}

The growth hormone receptor (GHR) 1A mRNA decreases after calving in the liver of Holstein dairy cows and may coordinate nutrient partitioning. The hypothesis that the decrease in GHR1A mRNA around the time of calving was characteristic of a second dairy breed was tested by examining Guernsey cows in addition to Holstein cows. Holstein and Guernsey cows were housed together and paired by parity and expected calving date. Liver biopsies and blood samples were collected prepartum $(\mathrm{d}-20 \pm 1)$ and postpartum on d 3, and d $14 \pm 1$. The amounts of GHR1A, GHR1B, GHR1C, and insulin-like growth factor (IGF)1 mRNA were determined by quantitative reverse transcription polymerase chain reaction. Blood concentrations of growth hormone $(\mathrm{GH})$ and IGF1 were measured by RIA. Both breeds underwent a decrease in GHR1A mRNA, a decrease in liver IGF1 mRNA, a decrease in blood IGF1, and an increase in blood GH after calving. The decrease in liver GHR1A and IGF1 mRNA after calving may be an inherent characteristic of dairy breeds that enables nutrient partitioning for greater milk production. Independent genetic selection in 2 dairy breeds seemingly exploited a similar mechanism, reduced GHR1A expression, to decrease blood IGF1 and increase blood GH, a key hormone involved in nutrient partitioning.

Key words: growth hormone receptor, insulin-like growth factor 1, dairy cow, nutrient partitioning

Nutrient partitioning during early lactation in dairy cattle is an essential physiological process that enables high peak milk yield (Bauman and Currie, 1980). The primary hormone responsible for nutrient partitioning is growth hormone (GH; Etherton and Bauman, 1998). Growth hormone binds to the growth hormone receptor (GHR) whose mRNA is expressed as 1 of 3 variants (GHR1A, GHR1B, or GHR1C mRNA; Jiang and Lucy, 2001). The amount of mRNA for GHR1A in the

Received October 2, 2008.

Accepted January 21, 2009.

${ }^{1}$ Corresponding author: LucyM@missouri.edu liver declines dramatically within 1 wk after calving in Holstein cows (Radcliff et al., 2003b). The decrease in GHR1A mRNA was associated with a decrease in GHR protein and the loss of GH action on the liver (Radcliff et al., 2003a). Changes in liver GHR1A may initiate nutrient partitioning because the loss of GHR reduced liver IGF1 synthesis and secretion into the bloodstream (Lucy et al., 2001). Lower blood IGF1 favors greater blood GH concentrations, because IGF1 provides the primary negative feedback loop for GH (LeRoith et al., 2001).

Our initial assumption was that the decrease in GHR and IGF1 after calving was a general physiological mechanism that occurs in all cattle. When Angus beef cows were sampled, however, the amount of GHR1A mRNA did not change after calving (Jiang et al., 2005). Likewise, when a strain of low-producing New Zealand dairy cattle was tested, the amount of GHR1A mRNA did not decrease at the time of calving (Lucy et al., 2009). To our knowledge, the only studies of GHR and IGF1 mRNA expression in periparturient dairy cows have been with Holstein cows. This study was conducted to determine if the GHR-related nutrient partitioning mechanisms that we were exploring in Holstein cows were present in a second dairy breed (in this case, Guernsey). If true, then the mechanisms may represent general mechanisms that are invoked when genetic selection for milk production is practiced. The specific objective was to determine whether Guernsey cows underwent changes in the somatotropic axis after calving that typify those found in Holstein cows.

Holstein ( $\mathrm{n}=9 ; 3$ primiparous and 6 multiparous) and Guernsey ( $\mathrm{n}=9 ; 4$ primiparous and 5 multiparous) cows were paired by parity and expected parturition date. The cows were housed in a confinement-style freestall barn at the University of Missouri Foremost Dairy Farm. Prepartum cows were fed a TMR consisting of corn silage, soy hulls, soybean meal, brome hay, and a vitamin and mineral premix. After calving, cows were milked twice daily and fed a TMR consisting of corn silage, alfalfa hay, alfalfa haylage, ground corn, soybean meal, whole cottonseeds, and a vitamin and mineral premix. The 305-d mature-equivalent milk yields for Holstein and Guernsey cows were 10,239 \pm 737 and 
Table 1. GenBank accession number, gene name, oligonucleotide primer sequence (forward and reverse primers; $5^{\prime}$ to $3^{\prime}$ ), location of the primer within the GenBank sequence, length of the amplicon, and amplification efficiency for the individual genes whose expression was measured by reverse transcription PCR

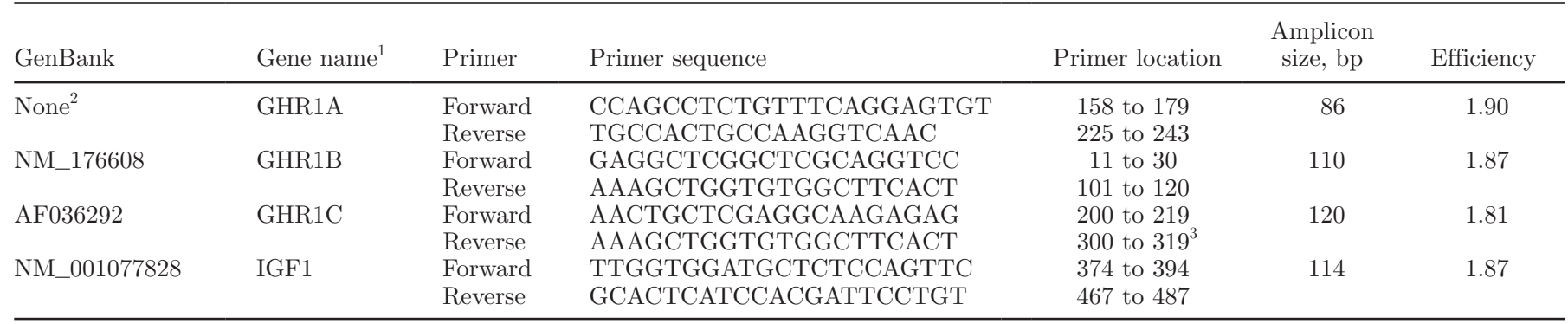

${ }^{1} \mathrm{GHR} 1 \mathrm{~A}, \mathrm{GHR} 1 \mathrm{~B}$, and GHR1C = 1A, 1B, 1C variants of growth hormone receptor (GHR) gene.

${ }^{2}$ The sequence is not in GenBank but was published by Hauser et al. (1990).

${ }^{3}$ The GenBank sequence for GHR1C is a partial sequence that does not contain exons 2 through 10 of the GHR. The primer location was calculated based on the assumption of a complete GHR sequence.

$6,989 \pm 699 \mathrm{~kg}$, respectively. Liver biopsies were taken prepartum $(\mathrm{d}-20 \pm 1)$ and postpartum on $\mathrm{d} 3$, and $\mathrm{d}$ $14 \pm 1$ by needle biopsy as described by Kobayashi et al. (1999). The tool used was a 12-gauge biopsy needle (15 cm long with a 20-mm notch; US Biopsy; Franklin, IN). Liver tissue was placed in a screw-cap microcentrifuge tube after collection and immediately frozen in liquid nitrogen. Long-term storage was at $-80^{\circ} \mathrm{C}$. Blood samples were collected into Vacutainer tubes containing EDTA (BD Vacutainer, Becton Dickinson, Franklin Lakes, NJ) by coccygeal venipuncture after each liver sample collection. The blood was placed on ice for transport to the laboratory and plasma was harvested by centrifugation and stored frozen at $-20^{\circ} \mathrm{C}$.

Total RNA was extracted from liver using the Trizol reagent (Invitrogen, Carlsbad, CA) according to the manufacturer's instructions. The integrity and purity of the extracted RNA were verified by measuring the ratio of absorbencies at 260 and $280 \mathrm{~nm}$ and by visual inspection of an RNA aliquot on a Tris-borate/EDTA (0.09 $M$ Tris-borate, $0.02 M$ EDTA) ethidium bromidestained agarose gel. The RNA was stored at $-80^{\circ} \mathrm{C}$ until use. Total RNA was transcribed into cDNA by using the SuperScript First Strand RT-PCR kit (Invitrogen). The reactions were carried out using $1 \mu \mathrm{g}$ of total RNA and were primed with random hexamers and oligo dT. Quantitative real-time reverse transcription-PCR was used to assay the amount of cDNA (i.e., mRNA) in each sample. The cDNA were amplified in an ABI Prism 7700 machine (Applied Biosystems, Foster City, CA) using the QuantiTect SYBR Green PCR Kit (Qiagen, Valencia, CA) and specific PCR primers for GHR1A, GHR1B, GHR1C, and IGF1 (Table 1). Each PCR 96-well plate contained a "no-template control" to ensure that there was no background contamination. Samples were assayed in triplicate. The threshold cycle $\left(\mathbf{C}_{\mathbf{T}}\right)$ for the test samples was subtracted from the $\mathrm{C}_{\mathrm{T}}$ for the control sample to obtain the change (delta) in $\mathrm{C}_{\mathrm{T}}\left(\Delta \mathrm{C}_{\mathrm{T}}\right)$. The amount of each mRNA (relative to the control sample) was calculated by using the equation: relative expression $=$ amplification efficiency ${ }^{\Delta \mathrm{CT}}$. The amplification efficiencies (derived from an analysis of $\mathrm{C}_{\mathrm{T}}$ in serially diluted samples) are presented in Table 1 and were approximately equal to 2 for the tested mRNA.

Plasma GH and plasma IGF1 were analyzed by validated RIA (Rhoads et al., 2008). Samples were analyzed in a single assay for the respective hormones. The intraassay coefficients of variation for plasma GH and IGF1 were 5 and $12 \%$, respectively.

Each of the 18 cows had 3 liver samples and 3 blood samples collected 11 sample prepartum and 2 samples postpartum (d 3 and d 14)]. Liver and blood samples (n $=54$ ) were analyzed for the respective liver mRNA and plasma hormones. Liver mRNA for GHR1A, GHR1B, GHR1C, and IGF1 and blood GH and IGF1 concentrations were analyzed for effects of breed (Holstein or Guernsey), parity (primiparous or multiparous), breed by parity, sample day relative to calving (prepartum, d 3 , or d 14), breed by day, parity by day, and parity by breed by day interactions. The analyses were conducted by using the mixed models procedure of SAS (PROC MIXED; SAS Institute, Cary, NC). The heterogeneous compound symmetry structure was used. Cow nested within breed by parity was included in the model as a random effect. Day was included in the model as a repeated variable. Results are reported as least squares means \pm the standard errors of the least squares means (output from the PROC MIXED analyses). Regression analyses were done with PROC REG of SAS. For presentation purposes, a $P>0.10$ was not considered statistically significant.

There was a tendency for an effect of parity $(P<$ $0.069 ; 19.6 \pm 3.9$ and $9.9 \pm 3.1$ relative units for prim- 


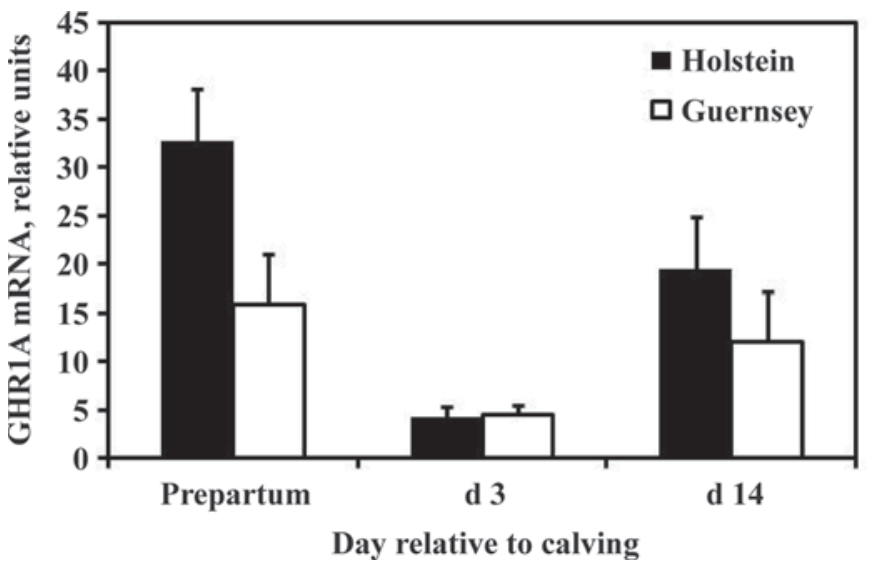

Figure 1. Fold change in growth hormone receptor (GHR) 1A mRNA gene expression in liver samples collected prepartum (d -20 \pm 1 ) and postpartum on $\mathrm{d} 3$ and $\mathrm{d} 14 \pm 1$ in lactating Holstein and Guernsey dairy cows. There was an effect of day $(P<0.001)$ and a tendency for a breed $\times$ day interaction $(P<0.056)$.

iparous and multiparous cows, respectively), an effect of day $(P<0.001)$, and a tendency for a breed by day interaction $(P<0.056)$ for GHR $1 \mathrm{~A}$ mRNA amount. Both Holstein and Guernsey cows underwent a decrease in GHR1A from prepartum to d 3 and a subsequent increase in GHR1A mRNA from d 3 to d 14 (Figure 1). The breed by day interaction for GHR1A likely reflected lower prepartum GHR1A mRNA in Guernsey cows. The main effects of breed, parity, day, and their interactions were not significant for the amount of GHR1B $(17.9 \pm 2.1)$ or GHR1C $(6.2 \pm 0.3)$ mRNA. The pattern of IGF1 mRNA was similar to that found for GHR1A mRNA (Figure 2) because there was a decrease in IGF1 after calving (effect of day $P<0.001$ ).

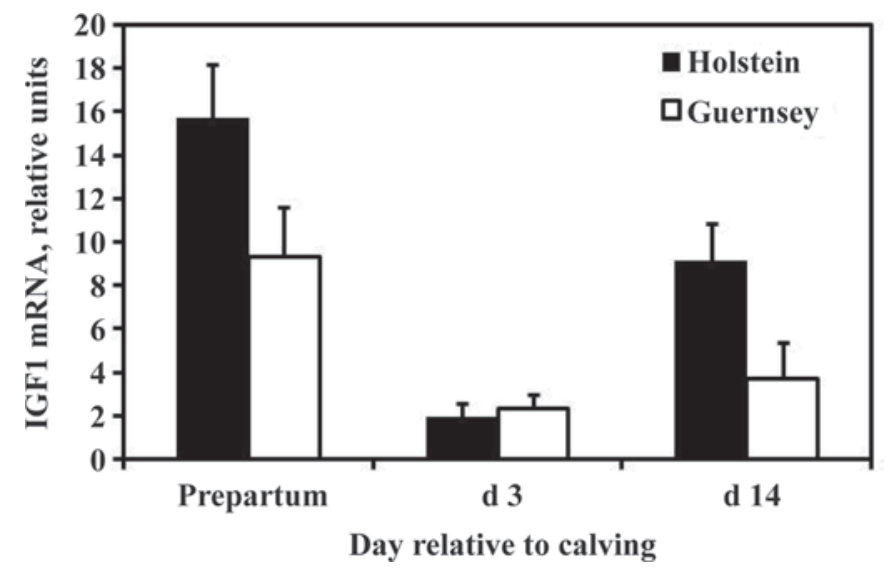

Figure 2. Fold change in IGF1 mRNA gene expression in liver samples collected prepartum $(\mathrm{d}-20 \pm 1)$ and postpartum on $\mathrm{d} 3$ and d $14 \pm 1$ in lactating Holstein and Guernsey dairy cows. There was an effect of day $(P<0.001)$ and a breed $\times$ day interaction $(P<0.021)$ for IGF1 mRNA.
There was a breed by day interaction for IGF1 $(P<$ 0.021 ) that likely reflected lesser prepartum and $\mathrm{d} 14$ IGF1 mRNA in Guernsey cows. The effect of parity was not significant for IGF1 mRNA. The IGF1 mRNA amount was correlated with the GHR1A mRNA amount $\left(\mathrm{r}^{2}=0.58 ; P<0.001 ;\right.$ IGF1 $\mathrm{mRNA}=0.32 \times \mathrm{GHR} 1 \mathrm{~A}$ mRNA + 2.5), but was not correlated with GHR1B or GHR1C mRNA.

Plasma IGF1 decreased and plasma GH increased after calving (effect of day for each hormone at $P<0.001$; Figures 3 and 4 ). There was a tendency for a breed by day interaction for plasma IGF1 $(P<0.065)$ that likely reflected lesser plasma IGF1 before and after calving (d 14) in Guernsey compared with Holstein cows. There was an effect of parity for plasma IGF1 $(P<0.006$; $75.1 \pm 5.7$ and $51.2 \pm 4.5 \mathrm{ng} / \mathrm{mL}$ for primiparous and multiparous, respectively). The effects of breed, parity, or interactions were not significant for plasma GH. Plasma IGF1 concentrations were correlated with liver IGF1 mRNA $\left(\mathrm{r}^{2}=0.47 ; P<0.001 ;\right.$ plasma IGF1 $=4.0$ $\times$ IGF1 mRNA +32.5$)$ and liver GHR1A mRNA $\left(\mathrm{r}^{2}=\right.$ $0.32 ; P<0.001$; plasma IGF1 $=1.4 \times$ GHR1A mRNA $+41.1)$. There was a lesser but significant correlation for plasma IGF1 and liver GHR1B $\left(\mathrm{r}^{2}=0.06 ; P<0.05\right.$; plasma IGF1 $=-0.5 \times$ GHR1B mRNA +68.8$)$ and no correlation between plasma IGF1 and liver GHR1C $(P>0.10)$.

Both Holstein and Guernsey cows underwent a decrease in GHR1A after calving (Figure 1), a decrease in liver IGF1 mRNA and blood IGF1 concentrations after calving (Figures 2 and 3), and an increase in plasma GH after calving. The observed similarities are of interest because each breed has undergone independent genetic selection for milk production beginning with the

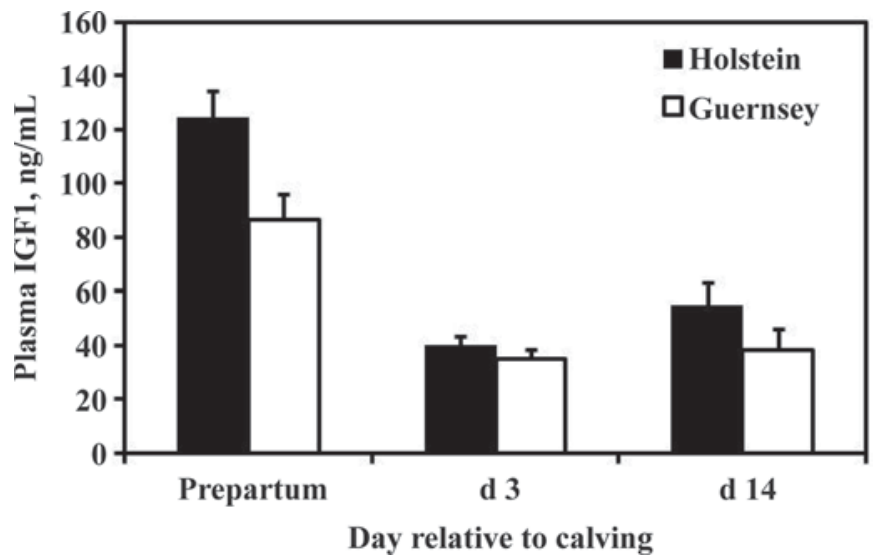

Figure 3. Plasma concentrations of IGF1 in blood samples collected prepartum $(\mathrm{d}-20 \pm 1)$ and postpartum on $\mathrm{d} 3$ and $\mathrm{d} 14 \pm 1$ in lactating Holstein and Guernsey dairy cows. There was an effect of day $(P<0.001)$ and a tendency for a breed $\times$ day interaction $(P<$ $0.065)$ for plasma IGF1. 


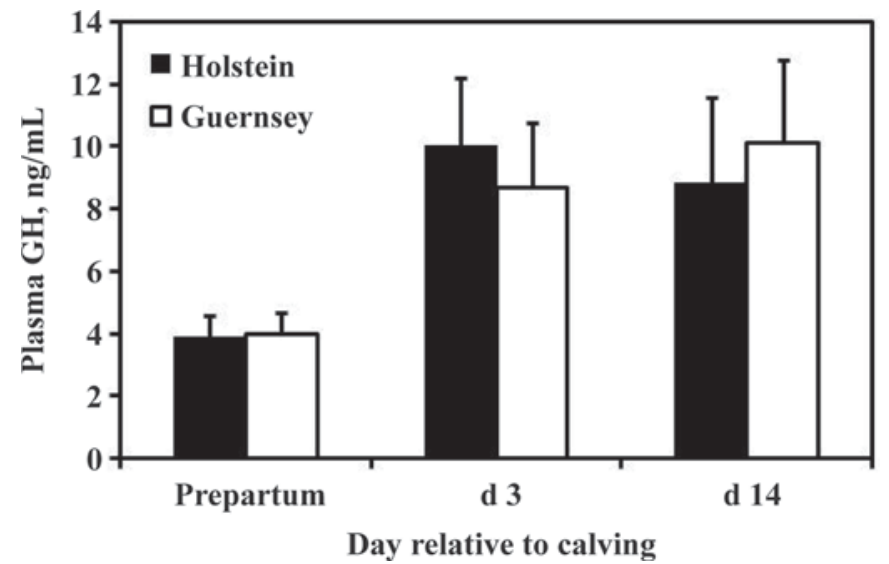

Figure 4. Plasma concentrations of growth hormone (GH) in blood samples collected prepartum ( $\mathrm{d}-20 \pm 1$ ) and postpartum on $\mathrm{d} 3$ and d $14 \pm 1$ in lactating Holstein and Guernsey dairy cows. There was an effect of day $(P<0.001)$, but the effects of breed and breed $\times$ day were not significant for plasma $\mathrm{GH}$.

establishment of each breed within the United States in the 19th century (Becker, 1973). A decrease in GHR1A and IGF1 mRNA, a decrease in blood IGF1, and an increase in blood GH after calving may be an inherent characteristic of dairy breeds that enables nutrient partitioning for greater milk production. Independent genetic selection in 2 dairy breeds exploited a similar mechanism (reduced GHR1A expression) to decrease blood IGF1 and increase blood GH, a key hormone involved in nutrient partitioning. Perhaps genetic modification of GHR function is the most efficient means through which nutrient partitioning can be affected. The mechanism of lesser GHR1A mRNA expression in early postpartum liver was seemingly capitalized upon unknowingly in 2 breeds undergoing genetic selection for milk production. The existence of QTL for milk production within the GHR locus (Blott et al., 2003; Viitala et al., 2006) supports the notion that the GHR gene is involved in nutrient partitioning and milk production.

Breed by day interactions were detected for GHR1A mRNA (Figure 1), IGF1 mRNA (Figure 2), and plasma IGF1 (Figure 3). The interactions seemingly arose from Guernsey cows having lesser mRNA (GHR1A and IGF1) or protein (plasma IGF1) in the prepartum and d 14 postpartum samples. The breeds were nearly identical for GHR1A mRNA, IGF1mRNA, and plasma IGF1 on d 3 postpartum. The interactions that we detected were either tendencies or not highly significant (ranging from $P<0.065$ to $P<0.021$ ). Whether or not the relative prepartum and $\mathrm{d} 14$ values are true characteristics of the individual breeds will need to be investigated in a larger study in which cows from multiple herds are sampled. If these differences do exist in the entire population of Holstein and Guernsey cows, then they may imply lesser GHR1A and IGF1 mRNA expression in Guernsey cows throughout lactation and the dry period. This focused study was not designed to detect these longer term breed differences.

In addition to answering the central questions outlined above, we confirmed several of our previous observations. We found a high correlation between GHR1A mRNA and IGF1 mRNA but failed to find or found a lesser correlation between GHR1B or GHR1C mRNA and IGF1. The correlation between GHR1A mRNA and IGF1 likely arose from the high correlation between GHR1A mRNA and GHR protein (Radcliff et al., 2003a) and the stimulatory effect of GH (through the GHR) on IGF1. Compared with GHR1A, GHR1B and GHR1C mRNA are generally less dynamic in their expression (as we observed in this study) and are lowly correlated with IGF1 (also observed in this study). There was a high correlation between liver IGF1 mRNA and blood IGF1 because liver synthesizes most of the IGF1 found in the bloodstream (Le Roith et al., 2001). Greater blood IGF1 concentrations in primiparous cows compared with multiparous cows were reported previously for Holstein cows (Lucy et al., 2009) and likely reflected aging of the somatotropic axis (Rosen, 2000).

The mRNA analyses did not include a correction for expression of a housekeeping gene. We have used cyclophilin and GAPDH in the past and the suitability of both genes was called into question in a subsequent study (Rhoads et al., 2003). More recently, JanovickGuretzky et al. (2007) concluded that ribosomal protein S9 was a suitable housekeeping gene for bovine liver. This transcript was assayed for in our samples and found unsuitable because its expression increased in the postpartum liver (data not shown). The simplest approach was to present the actual data without any attempt to normalize relative to a second gene. Although this approach has potential limitations, it eliminates the possibility that housekeeping gene expression was changing in an unpredictable manner that could compromise interpretation of the results. The observation that GHR1A and IGF1 mRNA undergo large changes in expression whereas GHR1B and GHR1C mRNA remain relatively stable argues against an RNA or cDNA quality problem that arose on one sample day but not the other. It is worth noting that liver IGF1 mRNA and blood IGF1 were measured by entirely independent procedures and their amounts were highly correlated. Liver tissue is the primary source of blood IGF1 protein (Le Roith et al., 2001). The correlation implies that our mRNA measurements were accurate.

In summary, Guernsey cows underwent changes in the somatotropic axis after calving that have previously been observed in Holstein cows. Specifically, both 
Holstein and Guernsey cows underwent a decrease in GHR1A mRNA, a decrease in liver IGF1 mRNA, a decrease in blood IGF1, and an increase in blood GH after calving.

\section{REFERENCES}

Bauman, D. E., and W. B. Currie. 1980. Partitioning of nutrients during pregnancy and lactation: A review of mechanisms involving homeostasis and homeorhesis. J. Dairy Sci. 63:1514-1529.

Becker, R. B. 1973. Dairy Cattle Breeds, Origin and Development. University of Florida Press, Gainesville, FL

Blott, S., J. J. Kim, S. Moisio, A. Schmidt-Küntzel, A. Cornet, P. Berzi, N. Cambisano, C. Ford, B. Grisart, D. Johnson, L. Karim, P. Simon, R. Snell, R. Spelman, J. Wong, J. Vilkki, M. Georges, F. Farnir, and W. Coppieters. 2003. Molecular dissection of a quantitative trait locus: A phenylalanine-to-tyrosine substitution in the transmembrane domain of the bovine growth hormone receptor is associated with a major effect on milk yield and composition. Genetics 163:253-266.

Etherton, T. D., and D. E. Bauman. 1998. Biology of somatotropin in growth and lactation of domestic animals. Physiol. Rev. 78:745761.

Hauser, S. D., M. F. McGrath, R. J. Collier, and G. G. Krivi. 1990. Cloning and in vivo expression of bovine growth hormone receptor mRNA. Mol. Cell. Endocrinol. 72:187-200.

Janovick-Guretzky, N. A., H. M. Dann, D. B. Carlson, M. R. Murphy, J. J. Loor, and J. K. Drackley. 2007. Housekeeping gene expression in bovine liver is affected by physiological state, feed intake, and dietary treatment. J. Dairy Sci. 90:2246-2252.

Jiang, H., and M. C. Lucy. 2001. Variants of the $5^{\prime}$-untranslated region of the bovine growth hormone receptor mRNA: Isolation, expression and effects on translational efficiency. Gene 265:45-53.

Jiang, H., M. C. Lucy, B. A. Crooker, and W. E. Beal. 2005. Expression of growth hormone receptor $1 \mathrm{~A}$ mRNA is decreased in dairy cows but not in beef cows at parturition. J. Dairy Sci. 88:1370-1377.

Kobayashi, Y., C. K. Boyd, C. J. Bracken, W. R. Lamberson, D. H. Keisler, and M. C. Lucy. 1999. Reduced growth hormone receptor
(GHR) messenger ribonucleic acid in liver of periparturient cattle is caused by a specific down-regulation of GHR 1A that is associated with decreased insulin-like growth factor I. Endocrinology 140:3947-3954

Le Roith, D., C. Bondy, S. Yakar, J. L. Liu, and A. Butler. 2001. The somatomedin hypothesis: 2001. Endocr. Rev. 22:53-74.

Lucy, M. C., H. Jiang, and Y. Kobayashi. 2001. Changes in the somatotropin axis associated with the initiation of lactation. J. Dairy Sci. 84(E Suppl.):E113-E119.

Lucy, M. C., G. A. Verkerk, B. E. Whyte, K. A. Macdonald, L. Burton R. T. Cursons, J. R. Roche, and C. W. Holmes. 2009. Somatotropic axis components and nutrient partitioning in genetically diverse dairy cows managed under different feed allowances in a pasture system. J. Dairy Sci. 92:526-539.

Radcliff, R. P., B. L. McCormack, B. A. Crooker, and M. C. Lucy. 2003a. Growth hormone (GH) binding and expression of $\mathrm{GH}$ receptor 1A mRNA in hepatic tissue of periparturient dairy cows. J. Dairy Sci. 86:3933-3940.

Radcliff, R. P., B. L. McCormack, B. A. Crooker, and M. C. Lucy. 2003b. Plasma hormones and expression of growth hormone receptor and insulin-like growth factor-I mRNA in hepatic tissue of periparturient dairy cows. J. Dairy Sci. 86:3920-3926.

Rhoads, M. L., J. P. Meyer, S. J. Kolath, W. R. Lamberson, and M. C. Lucy. 2008. Growth hormone receptor, insulin-like growth factor (IGF)-1, and IGF-binding protein-2 expression in the reproductive tissues of early postpartum dairy cows. J. Dairy Sci. 91:18021813.

Rhoads, R. P., C. McManaman, K. L. Ingvartsen, and Y. R. Boisclair. 2003. The housekeeping genes GAPDH and cyclophilin are regulated by metabolic state in the liver of dairy cows. J. Dairy Sci. 86:3423-3429.

Rosen, C. J. 2000. Growth hormone and aging. Endocrine 12:197201.

Viitala, S., J. Szyda, S. Blott, N. Schulman, M. Lidauer, A. MäkiTanila, M. Georges, and J. Vilkki. 2006. The role of the bovine growth hormone receptor and prolactin receptor genes in milk, fat and protein production in Finnish Ayrshire dairy cattle. Genetics $173: 2151-2164$ 